ISSN: $2338-4794$

Vol.6. No. 2 Mei-Agustus 2018

\title{
PENGARUH PELATIHAN DAN KEPEMIMPINAN TERHADAP KINERJA KARYAWAN PT. METISKA FARMA
}

\author{
Freddrick Tiagita Putra, B.W *) \\ *) Dosen Program Studi Manajemen FE UNKRIS \\ Alamat: Kampus UNKRIS, Jatiwaringin Jakarta Timut \\ Email : $\underline{\text { freddricktiagitaputra@ gmail.com }}$
}

\begin{abstract}
An effective training program can improve the performance, skills, attitudes and spirit of the organization (Gomez, et al, 2001). The implementation of training and development programs must have various benefits for greater career development for future responsibilities. The purpose of this study is to analyze simultaneously and partially learning and training on the performance of employees of PT. Metiska Farma, causing 84 research respondents. The research sampling technique uses saturated samples, which is all the amount of information used as research samples. Research analysis uses simple analysis and multiple regression with hypothesis testing using $t$ test and $f$ test. The results showed that there were both simultaneous and partial training and leadership on the performance of employees of PT. Metiska Farma.
\end{abstract}

Ke words : Training, leadership, and employee performance

\section{PENDAHULUAN}

Program pelatihan yang efektif
dapat meningkatkan keterampilan, sikap/moral dan potensi organisasi (Gomez, et al, 2001). Untuk melihat efektifitas program pelatihan dan pengembangan maka instansi perlu melakukan penilaian terhadap perubahan sikap dan keterampilan. Diperlukan penilaian terhadap perubahan sikap dan keterampilan para pegawai, atau peningkatan kinerja pegawai. Selain itu, penyelenggaraan pelatihan dan pengembangan diharapkan dapat mendukung karir pegawai yang dapat dicapai selama masa tugasnya. Penyelenggaraan program pelatihan dan pengembangan harus mempunyai berbagai manfaat bagi pengembangan karir jangka panjang yang membantu pegawai untuk menerima tugas dana tanggung jawab yang lebih besar di waktu yang akan datang.

Tujuan organisasi akan dapat tercapai apabila kerjasama diantara para pelaku organisasi berjalan dengan lancar. Seorang pemimpin tidak akan dapat mengendalikan suatu organisasi tanpa adanya kerjasama yang baik dengan bawahannya, hal ini dikarenakan operasionalisasi pekerjaan adalah tugas dari para pegawai. Dalam memberikan tugasnya seorang pemimpin terkadang menghadapi berbagai tingkah laku pegawai dalam menghadapi pekerjaannya. Diantaranya pegawai yang cepat tanggap dalam melaksanakan tugasnya, pegawai yang tidak mau atau tidak bisa melaksanakan pekerjaannya, dan pegawai yang acuh dalam menyelesaikan pekerjaannya, karena tidak adanya motivasi kerja.

Pemimpin merupakan simbol, panutan, pendorong, sekaligus sumber pengaruh, yang dapat mengarahkan berbagai kegiatan dan sumber daya organisasi guna mencapai tujuan instansi. Tidak mengherankan begitu banyak studi yang telah dilakukan oleh ilmuwan tentang kepemimpinan, menghasilkan informasi dan analisis tentang pentingnya pengetahuan pemimpin. Jadi apapun alasannya kepemimpinan tetap relevan untuk dikaji sebagai upaya peningkatan efisiensi dan efektivitas, serta produktivitas organisasi. 


\section{LANDASAN TEORI}

\section{Pelatihan}

Sikulla (2002) menyatakan bahwa, pelatihan merupakan bagian dari suatu proses pendidikan yang tujuannya adalah untuk meningkatkan kemampuan dan keterampilan khusus seseorang atau sekelompok orang. Sedangkan menurut Mello (1999), pelatihan adalah suatu proses belajar dengan menggunakan teknik dan metode tertentu untuk meningkatkan keterampilan kerja seseorang atau sekelompok orang.

Pelatihan kerja sebagai bagian dari pengembangan sumber daya manusia bertujuan membentuk dan menambah pengetahuan seseorang mengenai pekerjaan lingkungan kerja, serta cara mengerjakan sesuatu pekerjaan dengan cepat dan tepat. Pelatihan kerja diperlukan untuk mengembangkan sumber daya manusia mengingat bahwa dalam kenyataannya terdapat pengetahuan dan keterampilan yang secara khusus tidak diberikan dalam pendidikan formal. Pengetahuan dan keterampilan yang demikian pada umumnya diperoleh melalui pengalaman kerja maupun pelatihan yang diperoleh dari kursus atau pendidikan nonformal lainnya. Dengan program latihan yang teratur akan membentuk dan meningkatkan keterampilan tenaga kerja yang pada akhirnya akumulasi pendidikan dan latihan mampu meningkatkan produktivitas tenaga kerja (Halloran:1996).

\section{Kepemimpinan}

Kepemimpinan (leadership), merupakan hal yang sangat dominan di dalam manajemen, karena kepemimpinan maka proses manajemen akan berjalan dengan baik dan karyawan akan bergairah dalam melakukan tugasnya (Jossep,). Baik dan tidaknya suatu organisasi sangatlah tergantung daripada kecakapan dan kemampuan pimpinan dalam melaksanakan kepemimpinan untuk mengarahkan bawahannya. Demikian pula halnya keberhasilan ataupun kegagalan suatu organisasi terutama di lembaga-lembaga pemerintah sangat bergantung pada gaya kepemimpinan para pemimpin organisasi tersebut. Gaya kepemimpinan merupakan norma perilaku yang digunakan oleh pimpinan pada saat mencoba mempengaruhi bawahannya.

Gerakan dan dinamika sebuah organisasi sangat dipengaruhi oleh gaya kepemimpinan seorang pemimpin. Ada beberapa tipe kepemimpinan diantaranya dikemukakan oleh Kartono, (1998), sebagai berikut: a). Tipe kharismatik, yaitu tipe pemimpin ini memiliki kekuatan energi, daya tarik dan pembawaan yang luar biasa untuk mempengaruhi orang lain. b). Tipe paternalistis, yaitu tipe kepemimpinan yang kebapakan, dengan sifat sebagai orang dewasa yang kelihatan sangat berwibawa dan menjadi panutan. c). Tipe otokratis, yaitu tipe kepemimpinan berdasarkan diri pada kekuasaan dan paksaan yang mutlak dan harus dipatuhi. d). Tipe laissez faire, yaitu kepemimpinan pemimpin praktis tidak memimpin hanya menyerahkan tugas kepada bawahannya. e). Tipe demokratis, yaitu tipe pemimpin yang berorientasi pada manusia dan memberikan bimbingan yang efisien kepada pengikutnya.

\section{Kinerja Karyawan}

Timpe yang diterjemahkan oleh Cikmat (2000) mengemukakan bahwa: "kinerja adalah kulminasi tiga elemen yang saling berkaitan: Keterampilan, upaya kerja dan sifat keadaan-keadaan eksternal". Werther and Davis, yang dikutip oleh Zainun (2001) berpendapat bahwa "penilaian kinerja adalah suatu proses penilaian atas kinerja suatu organisasi termasuk penilaian prestasi karyawan". Porter and Lawler yang 
diterjemahkan oleh As'ad (1997) mengemukakan bahwa "kinerja adalah yang diperoleh seseorang dari perbuatannya".

Dessler (1997) adalah sebagai berikut: Bila penilaian gagal, itu semua terjadi karena alasan yang paralel dengan tiga langkah ini pendefinisian jabatan, penilaian kinerja, dan pemberian umpan balik. Beberapa penilaian gagal karena bawahan tidak diberitahu sebelumnya tentang apa persisnya yang diharapkan dari mereka dilihat dari segi kinerja yang baik yang lain gagal karena masalah dengan formulir atau prosedur yang digunakan untuk secara aktual menilai kinerja; seorang penyelia yang lunak mungkin menilai "tinggi" semua bawahannya, misalnya, walaupun banyak yang sesungguhnya tidak memuaskan.

Menurut Sastrodiningrat (2000), penilaian kinerja perorangan adalah suatu proses yang dilaksanakan dalam organisasi untuk menilai hasil kinerja perorangan dibandingkan dengan sasaran yang telah ditetapkan. Tujuan dari penilaian itu sendiri bertujuan untuk membantu manajer dalam rangka penempatan, penggajian dan membantu manager dalam mengambil keputusankeputusan lainnya. Penilaian kinerja berguna untuk menilai: a). Peningkatan kinerja: umpan balik dari penilaian kinerja dapat dipergunakan oleh seorang manager dan ahli personalia untuk mengambil tindakan-tindakan untuk meningkatkan Kinerja pegawai. b). Penyesuaian kompensasi untuk menentukan siapa yang berhak menerima kenaikan gaji. c). Keputusan penempatan untuk menentukan promosi, perpindahan dan penurunan jabatan. d). Keperluan pelatihan dan pengembangan; hasil kinerja yang kurang baik, tentu diperlukan pelatihan kembali. e). Perencanaan dan pengembangan karir; umpan balik kinerja diperlukan untuk keputusan karir. f). Kelemahan proses staffing; baik buruknya kinerja pegawai akan ditentukan oleh kuat lemahnya prosedur staffing pada bagian kekaryawanan. g). Ketidak-akuratan informasi; kinerja yang kurang baik menandakan adanya kesalahan dalam informasi mengenai analisa jabatan, perencanaan SDM, dan lain sebagainya. h). Kekeliruan rancangan kerja; kinerja yang kurang baik dapat disebabkan oleh kesalahan rancangan kerja.

i). Kesempatan kerja yang sama; penilaian kinerja yang diteliti akan menghindari penempatan seorang yang keliru dan diskriminatif. j). Tantangan External; kinerja seorang juga dipengaruhi oleh faktor external, misalnya keluarga, kesempatan dan sebagainya.

\section{METODE PENELITIAN}

\section{Populasi dan Sampel}

Setiap penelitian berdasarkan masalah yang ingin diteliti, mempunyai populasi tertentu dan dibatasi oleh ruang lingkup penelitian yang telah ditentukan yang dapat mendukung penelitian tersebut. Menurut Sugiyono (2003), populasi merupakan wilayah generalisasi yang terdiri dari objek atau subjek yang mempunyai kuantitas dan karakteristik tertentu yang ditetapkan oleh peneliti untuk dipelajari dan kemudian ditarik kesimpulannya.

Populasi yang menjadi subjek dalam penelitian ini adalah karyawan PT. Metiska Farma, yang berjumlah 84 orang responden. Pengambilan sampel penelitian menggunakan tehnik sampling jenuh yaitu semua anggota populasi digunakan menjadi sampel.

\section{Metode Pengumpulan Data}

Menurut Sekaran (2006) Metode pengumpulan data merupakan bagian integral dari desain penelitian yang meliputi wawancara (tatap muka, telepon, dan media elektronik), 
kuesioner secara pribadi, observasi individu, sedangkan metode yang dilakukan pada penelitian ini adalah penelitian mengambil sampel dari populasi dengan menggunakan kuesioner yang berisi tentang pelatihan, kepemimpinan dan Kinerja pegawain.

Metode yang digunakan dalam pengumpulan data dikelompokkan menjadi dua jenis data, yaitu : 1). Data primer; yaitu data yang dikumpulkan sendiri oleh peneliti secara langsung dari objek dengan teknikteknik yang digunakan sebagai berikut: a). Wawancara; yaitu teknik pengumpulan data yang dilakukan dengan cara tanya jawab langsung dengan para responden. b). Observasi; yaitu teknik pengumpulan data dengan cara melakukan pengambilan data langsung ke perusahaan dalam rangka mencocokkan data yang diperoleh dari angket dan wawancara. c). Kuesioner; yaitu suatu teknik pengumpulan data yang dilakukan dengan memberikan lembaran pertanyaan kepada responden. Metode ini dilakukan untuk memperoleh data primer yang diperlukan sebagai dasar analisa. Pembuatan daftar pertanyaan didasarkan pada indikator yang melekat pada masing-masing variabel yang digunakan dalam penelitian ini. Butir-butir pertanyaan yang dibuat dalam bentuk pilihan ganda, yang setiap butirnya berisi lima jawaban. Nilai jawaban yang diberikan memakai sistem skala Likert dengan skala 1 sampai dengan 5, penjelasan masing-masing jawaban pada skala likert dapat dilihat pada penjelasan tabel 1.

Tabel 1. Skala Questioner

\begin{tabular}{cc}
\hline Skala & Keterangan \\
\hline 5 & Sangat Setuju (SS) \\
4 & Setuju (S) \\
3 & Kurang Setuju (KS) \\
2 & Tidak Setuju (TS) \\
1 & SangatTidak Setuju (STS) \\
\hline
\end{tabular}

2). Data sekunder; adalah data yang diperoleh secara tidak langsung, yaitu data yang diperoleh dari penelitian pada perusahaan atau institusi, misal data administratif maupun data-data lain yang mendukung.

Tabel 2. Variabel dan Indikator Penelitian

\begin{tabular}{|c|c|c|c|}
\hline VARIABEL & SUB VARIABEL & INDIKATOR & $\begin{array}{c}\text { SKALA } \\
\text { DIKONVERSI }\end{array}$ \\
\hline \multirow[t]{4}{*}{ PELATIHAN } & $\begin{array}{l}\text { Pengetahuan } \\
\text { karyawan }\end{array}$ & $\begin{array}{l}\text { Pengetahuan karyawan } \\
\text { meningkat karyawan } \\
\text { lebih profesional }\end{array}$ & Ordinal \\
\hline & Keahlian & $\begin{array}{l}\text { Keahlian meningkat, } \\
\text { keahlian baru }\end{array}$ & \\
\hline & Keterampilan & $\begin{array}{l}\text { Karyawan lebih terampil, } \\
\text { karyawan menguasai } \\
\text { pekerjaan }\end{array}$ & \\
\hline & Sikap/perilaku & $\begin{array}{l}\text { Disiplin, profesional, } \\
\text { motivasi }\end{array}$ & \\
\hline
\end{tabular}




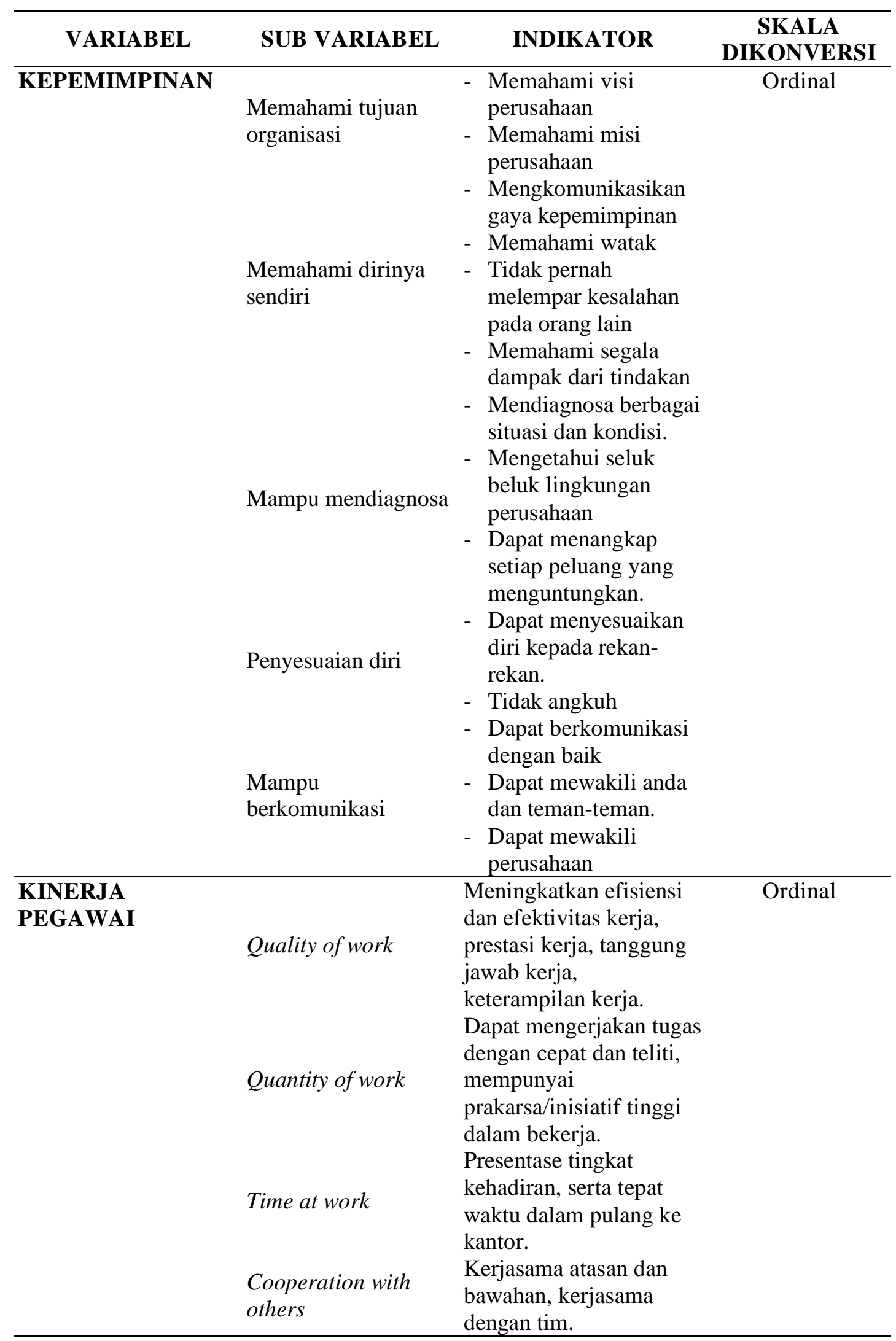

Sumber : Data Primer, diolah tahun 2017 


\section{HASIL DAN PEMBAHASAN}

\section{Hasil Penelitian \\ Uji Kualitas Data}

\section{Uji Validitas}

Penguji validitas ini dilakukan untuk menguji apakah tiap-tiap butir pernyataan telah mewakili indikator yang akan diselidiki. Menurut Masrun yang dikutip oleh Sugiyono, 2014, menyatakan bahwa biasanya syarat minimum untuk dianggap valid adalah $r$ $=0,30$. Jadi apabila korelasi antara butir-butir dengan skor total kurang dari
0,30 maka butiran dalam instrument tersebut dinyatakan tidak valid. Uji validitas dilakukan dengan melihat korelasi antar skor masing-masing item pernyataan dengan skor total.

\section{a. Uji Validitas Instrumen Pelatihan}

Dari hasil perhitungan korelasi skor tiap butir pernyataan instrument pelatihan dari 30 responden dengan jumlah pernyataan masing-masing variabel 10 pernyataan dengan total skor setiap responden diperoleh hasil disajikan dalam tabel sebagai berikut :

Tabel 3. Uji Validitas Variabel Pelatihan

\begin{tabular}{cccc}
\hline Kuesioner & R hitung & Rkritis & Kesimpulan \\
\hline Instrumen No. 1 & 0,937 & 0,220 & Valid \\
Instrumen No. 2 & 0,919 & 0,220 & Valid \\
Instrumen No. 3 & 0,904 & 0,220 & Valid \\
Instrumen No. 4 & 0,915 & 0,220 & Valid \\
Instrumen No. 5 & 0,900 & 0,220 & Valid \\
Instrumen No. 6 & 0,962 & 0,220 & Valid \\
Instrumen No. 7 & 0,914 & 0,220 & Valid \\
Instrumen No. 8 & 0,953 & 0,220 & Valid \\
Instrumen No. 9 & 0,952 & 0,220 & Valid \\
Instrumen No. 10 & 0,879 & 0,220 & Valid \\
\hline
\end{tabular}

Sumber : Data Primer, diolah tahun 2017

Berdasarkan tabel di atas, dapat

dari variabel pelatihan hasilnya adalah valid.

dilihat bahwa dari 10 butir pernyataan

\section{b. Uji Validitas Instrumen}

\section{Kepemimpinan}

Dari hasil perhitungan koefisien korelasi skor tiap butir pernyataan instrument kepemimpinan dari 30 responden dengan jumlah pernyataan masing-masing variabel 10 pernyataan dengan total skor setiap responden hasil disajikan dalam tabel sebagai berikut

Tabel 4. Uji Validitas Instrumen Kepemimpinan

\begin{tabular}{cccc}
\hline Kuesioner & R hitung & R kritis & Kesimpulan \\
\hline Instrumen No. 1 & 0,947 & 0,220 & Valid \\
Instrumen No. 2 & 0,881 & 0,220 & Valid \\
Instrumen No. 3 & 0,957 & 0,220 & Valid \\
Instrumen No. 4 & 0,932 & 0,220 & Valid \\
Instrumen No. 5 & 0,938 & 0,220 & Valid \\
Instrumen No. 6 & 0,918 & 0,220 & Valid \\
Instrumen No. 7 & 0,959 & 0,220 & Valid \\
Instrumen No. 8 & 0,963 & 0,220 & Valid \\
Instrumen No. 9 & 0,968 & 0,220 & Valid \\
Instrumen No. 10 & 0,901 & 0,220 & Valid \\
\hline Sumbr : Data Primer, diolah tahun 2017 & &
\end{tabular}

Sumber : Data Primer, diolah tahun 2017 
Berdasarkan tabel 4, dapat dilihat bahwa dari 10 butir pernyataan dari variabel kepemimpinan hasilnya adalah valid.

\section{c. Uji Validitas Instrumen Kinerja Karyawan}

Tabel 5. Uji Validitas Instrumen Kinerja pegawai

\begin{tabular}{cccc}
\hline Kuesioner & R hitung & Rkritis & Kesimpulan \\
\hline Instrumen No. 1 & 0,926 & 0,220 & Valid \\
Instrumen No. 2 & 0,963 & 0,220 & Valid \\
Instrumen No. 3 & 0,966 & 0,220 & Valid \\
Instrumen No. 4 & 0,974 & 0,220 & Valid \\
Instrumen No. 5 & 0,961 & 0,220 & Valid \\
Instrumen No. 6 & 0,931 & 0,220 & Valid \\
Instrumen No. 7 & 0,952 & 0,220 & Valid \\
Instrumen No. 8 & 0,940 & 0,220 & Valid \\
Instrumen No. 9 & 0,968 & 0,220 & Valid \\
Instrumen No. 10 & 0,950 & 0,220 & Valid \\
\hline
\end{tabular}

Sumber : Data Primer, diolah tahun 2017

Berdasarkan tabel 5, dapat dilihat bahwa dari 10 butir pernyataan dari variabel kinerja karyawan hasilnya adalah valid.

\section{Uji hipotesis}

1. Pengaruh simultan pelatihan dan kepemimpinan terhadap kinerja pegawai

\section{Tabel 6. Hasil Analisis Regresi \\ Berganda Pelatihan dan \\ Kepemimpinan Terhadap Kinerja Pegawai}

Coefficients $^{a}$

\begin{tabular}{|c|c|c|c|c|c|}
\hline \multirow[b]{2}{*}{ Model } & \multicolumn{2}{|c|}{$\begin{array}{c}\text { Unstandardized } \\
\text { Coefficients }\end{array}$} & \multirow{2}{*}{$\begin{array}{c}\begin{array}{c}\text { Standardized } \\
\text { Coefficients }\end{array} \\
\text { Beta }\end{array}$} & \multirow[b]{2}{*}{$t$} & \multirow[b]{2}{*}{ Sig. } \\
\hline & B & $\begin{array}{l}\text { Std. } \\
\text { Error }\end{array}$ & & & \\
\hline 1 (Constant) & 1,905 & ,694 & & 2,746 & ,000 \\
\hline Pelatihan & ,665 & ,078 & ,618 & 8,564 & 000 \\
\hline Kepemimpinan & ,378 & ,072 & ,379 & 5,246 &, 000 \\
\hline
\end{tabular}

Hasil analisis regresi berganda menjelaskan bahwa persamaan regresi yang disusun yaitu $\mathrm{Y}=1.905+0.665$ $\left(\mathrm{X}_{1}\right)+0.378\left(\mathrm{X}_{2}\right)$. Koefisien regresi variabel $\mathrm{X}_{1}$ bertanda positif menunjukkan adanya hubungan yang positif dari variabel pelatihan yang

menyebabkan kenaikan sebesar 0.665 terhadap Kinerja pegawai. Hal ini menunjukkan dengan adanya keberhasilan pelaksanaan pelatihan di PT. Metiska Farma maka Kinerja pegawai dapat meningkat. Koefisien regresi variabel $\mathrm{X}_{2}$ bertanda positif menunjukkan adanya hubungan positif dari variabel kepemimpinan yang menyebabkan kenaikan sebesar 0.378 terhadap Kinerja pegawai. Hal ini menunjukkan dengan adanya keberhasilan pelaksanaan kepemimpinan di PT. Metiska Farma dapat meningkatkan Kinerja pegawai. pelatihan dan kepemimpinan terhadap Kinerja pegawai signifikan atau tidak, dilakukan pengujian $f$ hitung dibandingkan $\mathrm{f}$ tabel atau dengan tingkat Signifikansi $f=0.000$ untuk $\mathrm{a}=0.05$. Berdasarkan perhitungan tersebut di atas dapat dinyatakan bahwa Nilai f hitung $=$ 21,030 lebih besar dibandingkan dengan $\mathrm{f}$ tabel 3.11 atau tingkat signifikan = 0.000 jauh lebih kecil dari 0.05, maka dapat diartikan terdapat pengaruh secara signifikan pelatihan dan kepemimpinan
Dari hasil perhitungan koefisien korelasi skor tiap butir pernyataan instrumen kinerja karyawan dari 30 responden dengan jumlah pernyataan masing-masing variabel 10 pernyataan dengan total skor setiap responden hasil disajikan dalam tabel 5

Pengujian hubungan simultan 
terhadap Kinerja pegawai PT. Metiska Farma.

\section{Pengaruh parsial Pelatihan terhadap kinerja pegawai}

Tabel 7. Hasil Analisis Regresi Sederhana Pelatihan Terhadap Kinerja Pegawai Coefficients $^{a}$

\begin{tabular}{|c|c|c|c|c|c|}
\hline \multirow[b]{2}{*}{ Model } & \multicolumn{2}{|c|}{$\begin{array}{l}\text { Unstandardized } \\
\text { Coefficients }\end{array}$} & \multirow{2}{*}{$\begin{array}{c}\begin{array}{c}\text { Standardiz } \\
\text { ed } \\
\text { Coefficients }\end{array} \\
\text { Beta }\end{array}$} & \multirow[b]{2}{*}{$t$} & \multirow[b]{2}{*}{ Sig. } \\
\hline & $B$ & Std. Error & & & \\
\hline 1 (Constant) & 2,202 & ,746 & & 4,294 & ,000 \\
\hline Pelatihan & 1,065 & ,018 & ,989 & 60,566 & ,000 \\
\hline
\end{tabular}

Hasil analisis regresi sederhana menjelaskan bahwa persamaan regresi yang disusun yaitu $\mathrm{Y}=2.202+1.065$ $\left(\mathrm{X}_{1}\right)$. Koefisien regresi variabel $\mathrm{X}_{1}$ bertanda positif menunjukkan adanya hubungan positif dari variabel pelatihan yang menyebabkan kenaikan sebesar 1.065 terhadap Kinerja pegawai. Hal ini menunjukkan keberhasilan program pelatihan bagi pegawai pada PT. Metiska Farma maka Kinerja pegawai akan semakin meningkat. Pengujian hipotesis dengan menggunakan uji t, yaitu dengan membandingkan $\mathrm{t}$ hitung dengan $t$ tabel dengan tingkat $\alpha=0,05$, hasilnya adalah $\mathrm{t}$ tabel $=1,671$ yang dilihat dari tabel distribusi $t$ (derajat kebebasan $=\mathrm{n}-2$ dengan uji dua pihak). Berdasarkan perhitungan tersebut di atas dapat dinyatakan bahwa Nilai $\mathrm{t}$ hitung $=$ 60.566 dan $\mathrm{t}$ tabel $=1.671$ atau $\mathrm{t}$ hitung $>\mathrm{t}$ tabel $(60.566>1.671)$, maka dapat diartikan terdapat pengaruh yang signifikan variabel pelatihan terhadap Kinerja pegawai PT. Metiska Farma.

\section{Pengaruh parsial kepemimpinan terhadap kinerja pegawai}

Tabel 8. Hasil Analisis Regresi

Sederhana Kepemimpinan Terhadap Kinerja Pegawai

\begin{tabular}{|c|c|c|c|c|c|}
\hline & \multicolumn{3}{|c|}{ Coefficients $^{a}$} & \multirow[b]{3}{*}{$t$} & \multirow[b]{3}{*}{ Sig. } \\
\hline \multirow[b]{2}{*}{ Model } & \multicolumn{2}{|c|}{$\begin{array}{l}\text { Unstandardized } \\
\text { Coefficients }\end{array}$} & \multirow{2}{*}{$\begin{array}{c}\begin{array}{c}\text { Standardized } \\
\text { Coefficients }\end{array} \\
\text { Beta }\end{array}$} & & \\
\hline & B & $\begin{array}{l}\text { Std. } \\
\text { Error }\end{array}$ & & & \\
\hline $1 \quad$ (Constant) & 1,248 & ,806 & & 11,547 & ,000 \\
\hline Kepemimpinan & ,984 & 019 & ,984 & 50,546 & ,000 \\
\hline
\end{tabular}

Hasil analisis regresi sederhana menjelaskan bahwa persamaan regresi yang disusun yaitu $\mathrm{Y}=1.248+0.984$ $\left(\mathrm{X}_{2}\right)$. Koefisien regresi variabel $\mathrm{X}_{2}$ bertanda positif menunjukkan adanya hubungan positif dari variabel kepemimpinan yang menyebabkan kenaikan sebesar 0,984 terhadap Kinerja pegawai. Hal ini menunjukkan dengan adanya keberhasilan penerapan model kepemimpinan di PT. Metiska Farma akan meningkatkan Kinerja pegawai.

Uji hipotesis dilakukan dengan menggunakan uji t, yaitu membandingkan nilai $t$ hitung dengan $t$ tabel dengan tingkat kepercayaan (a) = 0.05 , hasilnya adalah $\mathrm{t}$ tabel $=1.671$ yang dilihat dari tabel distribusi $t$ (derajat kebebasan $=n-2$ dengan uji dua pihak). Berdasarkan perhitungan tersebut di atas dapat dinyatakan bahwa nilai $\mathrm{t}$ hitung $=50.546$ dibandingkan dengan $\mathrm{t}$ tabel 1.671 atau $\mathrm{t}$ hitung $>\mathrm{t}$ tabel (50.546>1.671), maka dapat diartikan terdapat pengaruh yang signifikan kepemimpinan terhadap Kinerja pegawai PT. Metiska Farma.

\section{KESIMPULAN DAN SARAN}

\section{Kesimpulan}

Mengacu dari latar belakang masalah penelitian yang telah diuraikan di muka bahwa hal yang melatarbelakangi penelitian ini adalah untuk meneliti seberapa besar pelatihan 
dan kepemimpinan yang selama ini berkembang mempengaruhi kinerja karyawan PT. Metiska Farma, selanjutnya apakah kebijakan program pelatihan dan model kepemimpinan tersebut perlu untuk diperbaiki atau sebaliknya. Melalui hasil analisa dan pembahasan penelitian tentang pelatihan dan kepemimpinan dikaitkan dengan kinerja karyawan PT. Metiska Farma, diperoleh beberapa kesimpulan yang dapat menjawab pertanyaan. Kesimpulan itu adalah sebagai berikut: 1). Hasil penelitian menunjukkan bahwa pelatihan berpengaruh terhadap kinerja karyawan PT. Metiska Farma. Hal ini berarti bahwa makin tinggi keberhasilan program pelatihan yang diciptakan maka makin baik kinerja individu karyawan. 2). Hasil penelitian menunjukkan bahwa kepemimpinan berpengaruh terhadap kinerja karyawan PT. Metiska Farma. Hal ini berarti bahwa makin kondusif model kepemimpinan yang diterapkan berdasarkan visi dan misi perusahaan maka makin baik kinerja karyawan.

\section{Saran}

Setelah mengetahui pengaruh yang diberikan oleh variabel pelatihan dan kepemimpinan terhadap kinerja karyawan pada PT. Metiska Farma. Pada kesempatan ini peneliti mencoba untuk memberikan saran yang sekiranya dapat dijadikan rekomendasi khususnya bagi manajemen PT. Metiska Farma, yang dijadikan objek penelitian, maupun perusahaan sejenis dalam mengambil kebijakan-kebijakan untuk peningkatan kinerja karyawannya: 1). Untuk faktor pelatihan, diharapkan perusahaan dalam meningkatkan kinerja karyawannya dengan cara memperhatikan metode pelaksanaan pelatihan yang sudah dilaksanakan lebih ditingkatkan, karena masih ada karyawan yang mengikuti pelatihan dimana hasil kerjanya belum sesuai dengan harapan perusahaan. Sehingga hal ini patut diperhatikan untuk diperbaiki pelaksanaan pelatihan agar tidak terulang dikemudian hari, mengingat anggaran yang dikeluarkan perusahaan untuk melaksanakan program pelatihan tidaklah sedikit. 2). Pada faktor kepemimpinan diharapkan pemimpin hendaknya tidak segan untuk memberikan pujian atas hasil kerja karyawan, serta senantiasa memberikan pengarahan kepada karyawan dalam mengerjakan suatu pekerjaan, dengan begitu karyawan akan merasa diperhatikan dan pada akhirnya akan memberikan kepuasan tersendiri bagi karyawan.

\section{DAFTAR PUSTAKA}

Bernadin, Imam, Dasar-dasar Kependidikan, Ghalia Indonesia, 2001.

Cooper, Emory R., Business Research Method, $4^{\text {th }}$ Edition, Richard D. Irwin, Inc., USA.

Dessler, Gary, Manajemen Personalia, Alih Bahasa: Agus Dharma, Erlangga, Jakarta, 2001.

Djarwanto PS., Mengenai Beberapa Uji Statistik Dalam Penelitian, Liberty, Jogyakarta, 2001.

Enoch, Jusuf, Administrasi dan Supervisi Pendidikan, Edisi Ketiga, Kahwil, Jakarta, 2001

Faisal, Sanapiah, Format-format Penelitian Sosial, Rajawali Pers, Jakarta, 2002.

Flippo, Edwin B., Manajemen Personalia, Jilid II, Alih Bahasa: Moh. Masud, Erlangga, Jakarta, 2001.

Handoko, T. Hani, Manajemen Personalia dan Sumber Daya Manusia, BPFE, Yogyakarta, 2002.

Miner, John B., Organizational Behavior: Performance and Productivity, First Edition, Copyright 1988 by Random House, Inc, 2001. 
Nawawi, Hadari, Administrasi Pendidikan, Gunung Agung, Jakarta, 2001.

Neagley, Ross L. and Dean Evans, Handbook of Effective Supervision of Instruction, Prentice Hall, Inc, Englewood Cliffs, N.J., 2001.

Nitisemito, Alex S., Manajemen Personalia, Ghalia Indonesia, Jakarta, 2001.

Purwanto, M. Ngalim, Administrasi dan Supervisi Pendidikan, PT. Remaja Rosdakarya, Bandung, 2001

Riduan dan Tita Lestari, Statistik I, Alphabet, Bandung, 2001

Saydam Bc, TT., Gouzali, Manajemen Sumber Daya Manusia, PT. Gunung Agung, Jakarta, 2001.
Siagian, Sondang P., Manajemen Sumber Daya Manusia, Bumi Aksara, Jakarta, 2001.

Simamora, Henry, Manajemen Sumber Daya Manusia, STIE YKPN, Edisi Kedua, Jakarta, 2001.

Simanjuntak, Payaman C., Manajemen Sumber Daya Manusia, Jakarta, 2002.

Singarimbun, Masri, Metode Penelitian Survei, LP3ES, IKAPI, Jakarta, 2001.

Siswanto, Bedjo, Manajemen Tenaga Kerja, Sinar Baru, Bandung, 2001.

Werther JR., William B., Keith Davis, Human Resources and Personnel Management, Mc. Graw Hill, Fifth Edition, 2002. 